\title{
Pengaruh Good Governance dan Budaya Organisasi pada Kinerja Aparatur Penyelenggara Pemerintahan Desa di Kota Denpasar
}

\author{
Ni Putu Rika Raheni ${ }^{1}$ \\ I.G.A.M Asri Dwija Putri ${ }^{2}$ \\ ${ }^{1,2}$ Fakultas Ekonomi dan Bisnis Universitas Udayana (Unud), Bali, Indonesia \\ e-mail: rikaraheni@gmail.com
}

\begin{abstract}
ABSTRAK
Penelitian ini bertujuan untuk menguji pengaruh good governance dan budaya organisasi pada kinerja aparatur penyelenggara pemerintahan desa di Kota Denpasar. Jumlah desa dinas di Kota Denpasar yaitu 27 Desa. Responden dalam penelitian ini adalah perangkat desa yang telah diatur dalam Peraturan Menteri Dalam Negeri Republik Indonesia nomor 114 Tahun 2014 antara lain, Kepala Desa, Sekretaris Desa, Kaur Keuangan, Badan Permusyawaratan Desa (BPD), dan Lembaga Pemberdayaan Masyarakat (LPM) di masingmasing desa di Kota Denpasar. Jumlah sampel yang diperoleh yaitu 70 responden dengan menggunakan metode probability sampling dengan teknik Slovin. Metode pengumpulan data yang digunakan dalam penelitian ini adalah kuesioner. Teknik analisis data yang dilakukan adalah analisis Regresi Linier Berganda. Berdasarkan analisis yang dilakukan, hasil penelitian ini menunjukkan Good Governance dan Budaya Organisasi berpengaruh positif pada Kinerja Aparatur Penyelenggara Pemerintahan Desa di Kota Denpasar.
\end{abstract}

Kata kunci: Good Governance, Budaya Organisasi, Kinerja Aparatur.

\begin{abstract}
This study aims to examine the effect of good governance and organizational culture on the performance of village government administrators in the city of Denpasar. The number of service villages in the city of Denpasar is 27 villages. Respondents in this study were village officials among others, Village Heads, Village Secretaries, Finance Chiefs, Village Consultative Bodies (BPD), and Community Empowerment Institutions (LPM) in each each village in the city of Denpasar. The number of samples obtained was 70 respondents using probability sampling methods with Slovin techniques. The data collection method used in this study was a questionnaire. The data analysis technique performed is the analysis of Multiple Linear Regression. Based on the analysis conducted, the results of this study indicate Good Governance and Organizational Culture have a positive effect on the Performance of Village Government Organizing Apparatus in the City of Denpasar.

Keywords: Good governance, organizational culture, apparatus performance.
\end{abstract}

\section{PENDAHULUAN}

Sejak diberlakukannya otonomi daerah, pengembangan wilayah pedesaan semakin gencar dilakukan oleh pemerintah. Hal tersebut juga didukung dengan adanya program Presiden Republik Indonesia yaitu Nawa Cita prioritas ketiga. 
Ni Putu Rika Raheni dan I.G.A.M Asri Dwija Putri. Pengaruh ...

Adapun pernyataan dalam Nawa Cita prioritas ketiga yaitu membangun Indonesia dimulai dari pinggiran dengan memperkuat daerah-daerah dan desa dalam satu kerangka negara kesatuan. Dapat disimpulkan dari pernyataan tersebut bahwa pengembangan wilayah pedesaan merupakan hal yang sangat penting dalam pembangunan Indonesia. Desa merupakan lembaga formal pemerintah terkecil yang berlaku secara nasional di Indonesia dan telah diatur dalam Undang-Undang Nomor 6 Tahun 2014. Undang-undang tersebut disahkan pada sidang paripurna DPR RI. Berlakunya Undang-undang tentang desa tersebut bertujuan untuk memberikan pengakuan dan kejelasan kepada desa akan status dan kedudukannya dalam sistem ketatanegaraan Republik Indonesia.

Undang-Undang Nomor 6 Tahun 2014 juga menjelaskan tentang pengalokasian dana desa, yang kemudian diatur dalam Peraturan Pemerintah Republik Indonesia No. 22 Tahun 2015 tentang Dana desa. Dana desa merupakan dana yang bersumber dari Anggaran Pendapatan dan Belanja Negara (APBN) yang diperuntukkan bagi desa yang ditransfer melalui Anggaran Pendapatan dan Belanja Daerah (APBD) kabupaten/kota, dan digunakan untuk mendanai penyelenggaraan pemerintah, pelaksanaan pembangunan, pembinaan kemasyarakatan dan pemberdayaan masyarakat. Penetapan prioritas penggunaan dana desa dikelola berdasarkan tata kelola desa yang demokratis dengan tujuan mensejahterakan masyarakat. Dana desa dikelola oleh perangkat desa yang merupakan perwakilan dari masyarakat desa (Widasari \& Putri, 2018).

Dana desa mulai dikucurkan oleh pemerintah pada awal tahun 2015, dimana jumlah anggaran yang dialokasikan untuk dana desa mencapai Rp. 21 triliun. 
Tahun 2016 jumlah dana desa naik menjadi Rp. 47 triliun, dan tahun 2017 mencapai Rp. 60 triliun. Hal tersebut menunjukkan pengalokasian dana desa dari tahun ke tahun mengalami peningkatan. Tahun 2017 Provinsi Bali memperoleh dana desa sebesar Rp. 537.258.505.000 yang dibagi untuk 626 desa. Rata-rata setiap desa di Bali memperoleh bantuan sebesar Rp. 840 juta. Adapun wilayah dengan dana desa tertinggi yakni Kota Denpasar dengan nilai mencapai Rp. 1 miliar. Hal tersebut karena Kota Denpasar memiliki jumlah desa yang paling sedikit dengan penduduk paling banyak nomor dua di Bali setelah Buleleng.

Mengingat jumlah penduduk desa yang cukup besar dengan perangkat desa yang sedikit, maka pemerintah Kota Denpasar dituntut untuk mampu memberikan pelayanan yang maksimal untuk masyarakat. Perangkat Desa yang berada di Kota Denpasar mengelola dana desa yang cukup besar sehingga perlu adanya suatu tata kelola yang baik. Pengelolaan dana desa di Kota Denpasar sudah berjalan dengan baik. Menurut Kepala Dinas Pemberdayaan Masyarakat dan Desa (DPMD) Kota Denpasar I Made Mertajaya, penggunaan dana desa sudah bisa dilakukan dengan baik, dalam pos besarnya penggunaan dana desa tersebut untuk pembangunan fisik, pemberdayaan, penyelenggaraan pemerintahan desa dan pembinaan. Besarnya penggunaan dana tersebut sesuai dengan kondisi masing-masing desa. Sedangkan Kota Denpasar kondisi fisiknya rata-rata baik, maka dana tersebut lebih banyak digunakan untuk pemberdayaan. Pengelolaan dana desa yang sudah baik, akan lebih baik lagi diikuti dengan pelayanan yang baik. Agar pelayanan kepada masyarakat semakin meningkat, perangkat desa diwajibkan meningkatkan kinerja dalam peranan sebagai pelayan masyarakat. Perangkat desa diwajibkan 
Ni Putu Rika Raheni dan I.G.A.M Asri Dwija Putri. Pengaruh ...

oleh pemerintah Kota Denpasar untuk bekerja keras agar maksimalnya pelayanan terhadap masyarakat, karena tercapainya pembangunan desa sangat ditentukan oleh Kinerja Perangkat Desa (Kita, 2017).

Undang-Undang Dasar Republik Indonesia 1945 pasal 22D ayat (3) mengamanatkan bahwa pemerintah daerah berwenang untuk mengatur dan mengurus sendiri urusan pemerintahan menurut asas otonomi daerah. Hal tersebut diarahkan untuk mempercepat terwujudnya kesejahteraan masyarakat daerah melalui peningkatan pelayanan, pemberdayaan, dan peran serta masyarakat, serta peningkatan daya saing daerah dengan memperhatikan prinsip demokrasi, pemerataan, keadilan, keistimewaan dan kekhususan suatu daerah dalam Negara Kesatuan Republik Indonesia. Pemerintah desa berperan dalam pengelolaan proses sosial didalam masyarakat. Tentunya, pemerintah desa mengemban tugas yang sangat penting yaitu memberikan kehidupan yang sejahtera dan tentram untuk warganya, dengan memberikan pelayanan sosial yang baik. Guna mewujudkan peran tersebut, pemerintah perlu melakukan perubahan dengan meningkatkan pelayanan sehingga kinerja pemerintah kedepannya akan lebih baik.

Kinerja adalah gambaran pencapaian pelaksanaan suatu kegiatan/ program/kebijaksanaan dalam mewujudkan sasaran, tujuan, misi dan visi organisasi. Dalam situasi partisipatif, seseorang akan meningkatkan kinerja bila berada pada posisi yang lebih tinggi (Milani, 1975). Menurut Mahoney et al., (1963) kinerja manajerial adalah kecakapan manajer atau pemimpin suatu organisasi dalam melaksanakan kegiatan-kegiatan manajerial antara perencanaan, 
investigasi, koordinaasi, supervisi, pengaturan staf, negosiasi dan representasi. Aparatur pemerintah desa adalah keseluruhan pejabat Negara yang bekerja pada instansi pemerintahan desa. Pemerintahan desa adalah penyelenggara urusan pemerintahan dan kepentingan masyarakat setempat dalam sistem pemerintahan Negara Kesatuan Republik Indonesia, dalam menjalankan peran dan fungsinya kepala desa atau yang disebut dengan nama lain dibantu oleh perangkat desa sebagai unsur penyelenggara pemerintahan desa sesuai dengan Undang-Undang No. 6 Tahun 2014.

Kepala desa berkewajiban melaksanakan prinsip tata pemerintahan desa yang akuntabel, transparan, profesional, efektif dan efisien, bersih, serta bebas dari kolusi, korupsi, dan nepotisme dengan dibantu oleh perangkat desa. Upaya yang dapat dilakukan untuk meningkatkan kinerja pemerintahan yang lebih baik adalah good governance (Yang \& Suartana, 2017). Good Governance dapat diartikan menjadi suatu tata kelola pemerintahan yang baik. Secara sederhana pengertian good governance adalah seperangkat proses yang diberlakukan dalam suatu organisasi baik swasta maupun negeri untuk menentukan keputusan. Prinsip-prinsip good governance mampu meminimalisir terjadinya penyalahgunaan kekuasaan dan pengambilan keputusan yang salah dalam suatu organisasi, sehingga dapat meningkatkan kinerja suatu organisasi. Suatu tuntutan yang mampu mendukung kelancaraan dan keterpaduan pelaksanaan tugas dan fungsi penyelenggaraan pemerintah negara dan pembangunan dengan mempraktikkan prinsip-prinsip good governance (Halim \& Damayanti, 2007). 
Ni Putu Rika Raheni dan I.G.A.M Asri Dwija Putri. Pengaruh ...

Menurut Acintya \& Putri, (2015) good governance berpengaruh positif pada kinerja pemerintah.

Keberhasilan dalam meningkatkan kinerja suatu organisasi akan sangat efektif apabila setiap individu aparatur pemerintah memiliki kesadaran dan disiplin yang baik. Keberhasilan kinerja juga dapat dipengaruhi oleh budaya organisasi (Lestari, 2013). Budaya organisasi sangat penting dalam setiap organisasi, karena budaya organisasi merupakan kebiasaan yang terjadi dalam hirarki organisasi mengenai norma dan perilaku (Dzulkifli, 2013). Budaya organisasi juga merupakan salah satu bagian yang penting dalam meningkatkan kinerja, sebab budaya organisasi akan sangat mempengaruhi psikologis masingmasing pegawai, kelompok kerja, dan bahkan seluruh organisasi. Penelitian Wardani et al. (2016) menyatakan bahwa budaya organisasi mempunyai pengaruh pada kinerja organisasi. Sedangkan penelitian dari Asmara \& Widanaputra, (2017) menyatakan budaya organisasi tidak berpengaruh pada kinerja organisasi.

Hasil penelitian yang dilakukan oleh Mulyawan, (2009) yang menguji pengaruh good governance pada kinerja pemerintah daerah menunjukan hasil adanya pengaruh positif. Selain good governance, budaya organisasi juga dapat mempengaruhi kinerja organisasi. Menurut Holmes \& Marsden, (1996) budaya organisasi mempunyai pengaruh terhadap perilaku, cara kerja dan motivasi para manajer dan bawahannya untuk mencapai kinerja organisasi. Penelitian mengenai good governance dan budaya organisasi memang sudah banyak yang meneliti. Namun sepengetahuan penulis responden yang berlatar belakang pemerintahan desa masih sedikit yang meneliti. 
Menurut Pradipto (2008) Corporate governance merupakan proses dan struktur yang digunakan untuk mengarahkan dan mengelola bisnis dan urusan urusan perusahaan dalam rangka meningkatkan kemakmuran bisnis dan akuntabilitas perusahaan dengan tujuan utamanya adalah mewujudkan nilai pemegang saham dalam jangka panjang dengan tetap memperhatikan kepentingan stakeholders yang lain. Good Governance bisa diartikan sebagai suatu pelaksanaan manajemen pembangunan yang bertanggungjawab dan sejalan dengan prinsip demokrasi yang efisien. Penerapan good governance membantu aparatur pemerintah dalam pengambilan keputusan yang efektif dalam rangka meningkatkan kemakmuran masyarakat dan meningkatkan pelayanan bagi prinsipal yaitu masyarakat. Dengan menerapkan Good Governance akan dapat meminimalisir kesalahan yang dilakukan oleh agen yaitu aparatur pemerintah.।

Tata kelola perusahaan yang baik di Indonesia didengungkan dan terjadi di era reformasi tahun 1998. Lahirnya wacana good governance berakar dari penyimpangan-penyimpangan yang terjadi dalam praktek pemerintahan, seperti Korupsi, Kolusi dan Nepotisme (KKN). Penyelenggaraan pemerintahan yang bersifat tidak transparan, nonpartisipatif serta sentralisasi, menumbuhkan rasa tidak percaya dikalangan masyarakat bahkan menimbulkan antipati terhadap pihak pemerintah. Masyarakat sangat tidak puas terhadap kinerja pemerintah yang selama ini dipercaya sebagai penyelenggara urusan publik. Berbagai ketidakpuasan dan kekecewaan akhirnya melahirkan tuntutan dari masyarakat untuk mengembalikan dan melaksanakan penyelenggaraan pemerintah yang ideal, 
Ni Putu Rika Raheni dan I.G.A.M Asri Dwija Putri. Pengaruh ...

sehingga good governance tampil sebagai upaya untuk menjawab berbagai keluhan masyarakat atas kinerja birokrasi yang telah berlangsung.

Tata kelola pemerintahan yang baik merupakan serangkaian proses interaksi sosial politik antara pemerintahan dengan masyarakat dalam berbagai bidang yang berkaitan dengan kepentingan masyarakat dan intervensi pemerintah atas kepentingan-kepentingan tersebut (Muhammad, 2017). Tata Kelola yang baik atau Good Governance merupakan suatu cara mengelola urusan-urusan publik dan tata pemerintahan yang mencakup seluruh mekanisme, proses dan lembagalembaga dimana warga dan kelompok masyarakat mengutarakan kepentingan mereka, menggunakan hak hukum, memenuhi kewajiban dan menjembatani perbedaan-perbedaan diantara mereka (Mardiasmo, 2004). Halim \& Damayanti, (2007) menyatakan bahwa Good Governance adalah penyelenggaraan pemerintah yang solid dan bertanggungjawab, serta efisien dan efektif dengan menjaga interaksi yang konstruktif diantara domain-domain negara, sektor swasta dan masyarakat.

Berdasarkan Peraturan Pemerintah No. 101 tahun 2000 pengertian Good Governance adalah pemerintahan yang mengembangkan dan menetapkan prinsipprinsip profesionalitas, akuntabilitas, transparansi, pelayanan prima, demokrasi, efisiensi, efektifitas, supremasi hukum dan dapat diterima oleh seluruh masyarakat. Menurut Organisation for Economic Co-Operation and Development atau disingkat OECD, (2002) terdapat unsur-unsur penting dalam corporate governance, yaitu: Fairness (keadilan), Tranparency (transparansi), Accountability (akuntabilitas), dan Responsibility (responsibilitas). Dengan 
corporate governance, keputusan-keputusan penting perusahaan tidak lagi hanya ditetapkan oleh satu pihak yang dominan, akan tetapi ditetapkan setelah mendapatkan masukan dan dengan mempertimbangkan kepentingan berbagai pihak yang berkepentingan (stakeholders).

Terdapat beberapa konsep yang menjelaskan pengertian mengenai budaya organisasi. Menurut Yamin, (2014) budaya organisasi merupakan kebiasaankebiasaan yang terjadi dalam hirarki organisasi yang mewakili norma-norma perilaku dan diikuti oleh para anggota dalam organisasi, maka budaya organisasi akan memberikan suasana psikologis bagi semua anggota, bagaimana mereka bekerja, bagaimana berhubungan dengan atasan maupun rekan sekerja dan bagaimana menyelesaikan masalah merupakan wujud budaya yang khas bagi setiap organisasi. Budaya dapat dibagi dalam beberapa tingkatan, antara lain: nasional, daerah, gender, generasi, kelas social, organisasional perusahaan (Hofstede, 1984).

Budaya organisasi yang kuat dapat ditunjukkan pada nilai-nilai inti organisasi yang dipegang teguh dan dijunjung bersama. Budaya organisasi akan semakin kuat apabila semakin banyak anggota organisasi menerima nilai-nilai inti dan berkomitmen lebih besar terhadap nilai tersebut. Dengan kuatnya organisasi akan membantu memberikan kepastian bagi seluruh sumber daya manusia untuk meningkatkan kegiatan dalam usaha peningkatan kinerja.

Budaya organisasi yang lemah akan berdampak negatif bagi suatu organisasi yang ditandai dengan tugas-tugas yang tidak dapat dilaksanakan dengan baik. Budaya yang lemah tidak mampu memberikan dorongan untuk maju 
bersama organisasi. Hal ini dapat dilihat dari kurangnya motivasi dalam bekerja, timbul kecurigaan-kecurigaan, komunikasi yang kurang lancar, lunturnya loyalitas pada tugas utama yang diberikan.

Budaya organisasi dapat menjadi salah satu yang penting untuk meningkatkan kinerja. Budaya organisasi memiliki lebih banyak pengaruh pada kinerja organisasi dengan mempengaruhi psikologis masing-masing pegawai, kelompok kerja, dan bahkan seluruh organisasi. Organisasi dengan budaya yang kuat hampir selalu melakukan tugas dengan lebih baik. Adapun yang menjadi indikator dari budaya organisasi menurut Jatilaksono \& Indartono, (2016) yaitu Inovatif memperhitungkan resiko, norma yang dibentuk berdasarkan kesepakatan menyatakan bahwa setiap pegawai akan memberikan perhatian yang sensitif terhadap segala pemasalahan yang mungkin dapat membuat resiko kerugian bagi kelompok dan oragnisasi secara keseluruhan; memberi perhatian pada setiap masalah secara detail di dalam melakukan pekerjaan akan menggambarkan ketelitian dan kecermatan karyawan dalam melakukan pekerjaannya; berorientasi terhadap hasil yang akan dicapai, suvervisi seorang manajer terhadap bawahannya merupakan salah satu cara manajer untuk mengarahkan dan memberdayakan staf; berorientasi terhadap keputusan yang mempengaruhi karyawan karena mempertimbangkan efek atas hasil yang dicapai; berorientasi kepada semua kepentingan pegawai, keberhasilan atau kinerja organisasi salah satunya ditentukan kekompakan tim kerja (team work), di mana kerjasama tim dapat dibentuk jika pimpinan dapat melakukan supervisi dengan baik; agresif dalam bekerja, produktivitas yang tinggi dapat dihasilkan apabila performa pegawai 
dapat memenuhi standar yang dibutuhkan untuk melakukan tugasnya; mempertahankan dan menjaga stabilitas kerja, performa yang baik dari karyawan harus didukung oleh kesehatan yang prima.

Konsep kinerja (performance) dapat didefinisikan sebagai sebuah pencapain hasil atau degree of accomplishtment (Keban, 1995). Hal ini berarti bahwa, kinerja suatu organisasi dapat dilihat dari sejauh mana organisasi mencapai tujuan yang didasarkan pada tujuan yang sudah ditetapkan sebelumnya. Kinerja merupakan hasil dari kegiatan kerjasama diantara anggota atau komponen organisasi dalam rangka mewujudkan tujuan organisasi. Kinerja dikatakan sebagai hasil (output) dari suatu proses tertentu yang yang dilakukan oleh seluruh komponen organisasi terhadap sumber-sumber tertentu yang digunakan (input). Selanjutnya kinerja merupakan hasil dari serangkaian proses kegiatan yang dilakukan untuk mencapai tujuan tertentu organisasi.

Pengertian aparatur adalah keseluruhan pejabat negara atau organ pemerintahan yang bertugas melaksanakan suatu kegiatan yang berhubungan dengan tugas dan kewajiban sebagai tanggung jawab yang dibebankan oleh negara kepadanya (Widjaja, 2005). Dengan demikian aparatur desa adalah semua unsur yang mempunyai peran penting dan terlibat di dalam lingkungan desa. Kinerja Aparatur dapat disimpulkan seluruh pencapaian pelaksanaan suatu kegiatan/program atau kebijaksanaandalam melaksanakan kegiatan-kegiatan manajerial antara perencanaan, investigasi, koordinaasi, supervisi, pengaturan staf, negosiasi dan representasi dalam mewujudkan sasaran, tujuan, misi dan visi 
Ni Putu Rika Raheni dan I.G.A.M Asri Dwija Putri. Pengaruh ...

organisasi oleh semua unsur yang mempunyai peran di dalam lingkungan desa (Kita, 2017).

Kinerja Manajerial menurut Mahoney et al., (1963) adalah kinerja para individu anggota organisasi dalam kegiatan-kegiatan manajerial. Kinerja Aparatur diukur dengan menggunakan indikator sebagai berikut, perencanaan, yaitu tindakan yang dibuat berdasarkan fakta dan asumsi mengenai gambaran kegiatan yang dilakukan pada waktu yang akan datang guna mencapai tujuan yang dinginkan. Investigasi, yaitu upaya yang dilakukan untuk menumpulkan dan mempersiapkan informasi dalam bentuk laporan-laporan, catatan dan analisa pekerjaan untuk dapat mengukur hasil pelaksanaannya. Koordinasi, yaitu menyelaraskan tindakan yang meliputi pertukaran informasi dengan orang-orang dalam unit organisasi lainnya, guna dapat berhubungan dan menyesuaikan program yang akan dijalankan. Evaluasi, yaitu penilaian atas usulan atau kinerja yang diamati dan dilaporkan. Supervisi, yaitu mengarahkan, memimpin dan mengembangkan potensi bawahan serta melatih dan menjelaskan aturan-aturan kerja kepada bawahan. Staffing, yaitu memelihara dan mempertahankan bawahan dalam suatu unit kerja, menyeleksi pekerja baru, menempatkan dan mempromosikan pekerja tersebut dalam unitnya atau unit kerja lainnya. Negosiasi, yaitu upaya untuk memperoleh kesepakatan dalam hal pembelian, penjualan atau kontrak untuk barang-barang dan jasa. Representasi, yaitu menyampaikan informasi tentang visi, misi dan kegiatan-kegiatan organisasi dengan menghadiri pertemuan kelompok sejenis dan konsultasi dengan intansiinstansi lain. Kinerja secara keseluruhan, yaitu hasil dari pelaksanaan seluruh 
kegiatan dari perencanaan sampai pertanggungjawaban laporan keuangan. Pencapaian target, yaitu pencapaian antara perencanaan dengan realisasi kegiatan yang telah disusun.

Hubungan keagenan merupakan suatu perjanjian antara satu atau lebih pihak prinsipal yang memperkerjakan agen (Jensen \& Meckling, 1976). Pihak agen memiliki tanggung jawab dan diharapkan memberikan pelayanan kepada pihak prinsipal. Teori keagenan adalah adanya hubungan keagenan dimana suatu pihak tertentu (prinsipal) mendelegasikan tugas kepada pihak lain (agen) untuk melakukan suatu pekerjaan (Eisenhardt, 1989).

Manajer sebagai pengelola perusahaan, tentu akan lebih banyak mengetahui informasi internal dan prospek perusahaan dibandingkan dengan pemegang saham. Adanya ketidakseimbangan penguasaan informasi akan memicu timbulnya asimetri informasi. Dengan adanya asimetri informasi tersebut akan memberi kesempatan kepada manajer untuk melakukan manajemen laba sehingga akan menyesuaikan pemegang saham mengenai kinerja ekonomi perusahaan (Sabrinna, 2010). Sifat mementingkan diri sendiri dengan mengutamakan kepentingan pribadi dapat dicegah dengan menerapkan good governance. Timbulnya konsep Good Governance berkaitan dengan principalagency theory, yaitu menghindari konflik antara prinsipal dan agennya.

Menurut Hasanah \& Suartana, (2014) pada instansi pemerintah daerah agen melaksanakan perencanaan, pelaksanaan dan pelaporan terkait dengan anggaran daerah sedangkan prinsipal memiliki peran dalam pengawasan. Hubungan keagenan mengharuskan pemerintah untuk melakukan apa yang 
Ni Putu Rika Raheni dan I.G.A.M Asri Dwija Putri. Pengaruh ...

menjadi kepentingan pengguna informasi keuangan pemerintah sebagai prinsipal. Pemerintah selaku manajemen dalam hal ini, harus bertanggungjawab terhadap wewenang yang diberikan oleh masyarakat selaku prinsipal. Pemerintah desa wajib memberikan laporan pertanggungjawaban serta perencanaan dan pengelolaan sumber daya yang tertuang dalam Anggaran Pendapatan dan Belanja Desa (APBDes).

Penelitian Asian Development Bank, (1995) mendapatkan hasil bahwa terdapat korelasi yang positif antara praktik tata kelola pemerintahan yang baik dengan hasil pembangunan yang lebih baik. Selain itu, praktik tata kelola pemerintahan yang baik juga dapat meningkatkan iklim keterbukaan, partisipasi, dan akuntabilitas sesuai dengan prinsip-prinsip dasar tata kelola pemerintahan yang baik pada sektor publik. Good Governance merupakan penyelenggaraan pemerintah yang solid dan bertanggunjawab, serta efisien dan efektif dengan menjaga interaksi yang konstruktif diantara domain-domain negara, sektor swasta dan masyarakat (Halim \& Damayanti, 2007).

Hasil penelitian sebelumnya yang dilakukan oleh Yang \& Suartana, (2017) menyatakan Good Governance berpengaruh positif pada Kinerja Pemerintahan Daerah. Wardani et al., (2016) menyatakan penerapan Good Governance berpengaruh signifikan pada pemerintahan di Kota Bandung, dimana terdapat korelasi yang sangat kuat antara penerapan prinsip good governance pada kinerja pemerintah daerah. Dari uraian tersebut dapat disimpulkan bahwa semakin baik penerapan good governance maka baik pula kinerja pemerintahan daerah tersebut. $\mathrm{H}_{1}$ : Penerapan Good Governance berpengaruh positif pada kinerja aparatur Penyelenggara Pemerintahan Desa di Kota Denpasar. 
Budaya organisasi yang baik menjadi penentu dari tata kelola perusahaan yang baik, terbentuk dan berkembangnya manajemen, kuatnya tanggung jawab sosial dari instansi terhadap lingkungan dan semangat untuk menjaga keunggulan instansi (Lestari, 2013). Budaya organisasi dapat meningkatkan stabilitas sosial karena merupakan perekat sosial yang membantu mempersatukan organisasi. Dapat disimpulkan bahwa budaya organisasi merupakan inti dari organisasi sebab, dalam budaya organisasi terdapat filosofi, visi dan misi organisasi.

Budaya organisasi menjadi salah satu hal yang penting untuk meningkatkan kinerja. Budaya organisasi memiliki lebih banyak pengaruh pada kinerja organisasi dengan mempengaruhi psikologis masing-masing pegawai, kelompok kerja, dan bahkan seluruh organisasi (Jatilaksono \& Indartono, 2016). Budaya organisasi mengacu kepada sistem makna bersama yang dianut oleh anggota-anggota organisasi yang membedakan organisasi itu dari organisasi lain, suatu sistem nilai budaya yang tumbuh menjadi kuat mampu memacu organisasi kearah perkembangan yang lebih baik (Robbins, 2006).

Penelitian Soraya \& Suardana, (2018) yang menggunakan budaya organisasi sebagai pemoderasi mendapatkan hasil bahwa budaya organisasi memperkuat kinerja, semakin kuat budaya organisasi maka semakin kuat pula kinerja suatu organisasi. Penelitian Wardani et al., (2016) menyatakan bahwa budaya organisasi mempunyai pengaruh pada kinerja organisasi. Jadi dapat disimpulkan bahwa budaya organisasi berpengaruh terhadap kinerja organisasi. Berdasarkan penelitian terdahulu atas dasar psikologi dan sosiologiyang menyatakan budaya organisasi berpengaruh terhadap kinerja, sehingga dapat 
Ni Putu Rika Raheni dan I.G.A.M Asri Dwija Putri. Pengaruh ...

disimpulkan bahwa semakin baik budaya suatu organisasi, maka kinerja yang dihasilkan akan semakin baik pula, sehingga visi misi organisasi yang telah ditetapkan akan terwujud, maka dengan demikian dapat dirumuskan hipotesis sebagai berikut.

$\mathrm{H}_{2}$ : Budaya organisasi berpengaruh positif pada kinerja aparatur Penyelenggara Pemerintahan Desa di Kota Denpasar.

\section{METODE PENELITIAN}

Penelitian ini dilakukan di Kota Denpasar, yaitu pada Pemerintahan Desa di Kota Denpasar. Obyek penelitian ini adalah good governance, budaya organisasi, dan kinerja aparatur penyelenggara pemerintahan desa di Kota Denpasar.

Populasi dari penelitian ini adalah penyelenggara pemerintahan desa yaitu Kepala Desa, Sekretaris Desa, Kaur Keuangan, unsur Badan Permusyawaratan Desa (BPD), dan unsur Lembaga Pemberdayaan Masyarakat (LPM) yang telah diatur dalam Peraturan Menteri Dalam Negeri Republik Indonesia nomor 114 Tahun 2014. Penelitian ini dilakukan pada desa dinas di Kota denpasar. Terdapat 27 desa dinas di Kota Denpasar dan setiap desa ditentukan 5 orang penyelenggara pemerintahan desa yang berkedudukan di desa tersebut. Jadi populasi berjumlah 27 desa $x 5$ responden $=135$ responden.

Sampel dalam penelitian ini akan diperkecil dengan pengukuran menggunakan teknik Slovin. Penelitian ini menggunakan rumus Slovin agar jumlah sampel representative sehingga dapat digeneralisasikan. Dalam hal ini:

$$
n=\frac{N}{\left(1+N e^{2}\right)} \text {. }
$$


Keterangan:

$$
\begin{aligned}
\mathrm{n} & =\text { jumlah anggota sampel } \\
\mathrm{N} & =\text { jumlah anggota populasi } \\
\mathrm{e} & =\text { nilai kritis (batas ketelitian } 0,10) \\
\mathrm{n}=\mathrm{N} /\left(1+135(0,1)^{2}\right) & \\
= & 135 /\left(1+135(0,1)^{2}\right) \\
= & 57,45 ; \text { disesuaikan oleh peneliti menjadi } 70 \text { responden }
\end{aligned}
$$

Jadi jumlah minimal responden dalam penelitian ini adalah 58(dibulatkan). Sampel disesuaikan oleh peneliti dengan menambah jumlah responden sehingga sampel dalam penelitian ini adalah 70 responden di Kota Denpasar.

Alat analisis data yang digunakan adalah satatistik inference yang bertujuan untuk menguji hipotesis dengan menggunakan Regresi Linier Berganda melalui program komputer SPSS dengan rumus sebagai berikut.

$\mathrm{Y}=\mathrm{a}+\mathrm{b}_{1} \mathrm{x}_{1}+\mathrm{b}_{2} \mathrm{x}_{2}+\mathrm{e}$

Dimana:

$\mathrm{Y} \quad=$ Variabel terikat (kinerja aparatur)

a $\quad=$ konstanta

$\mathrm{b}_{1}, \mathrm{~b}_{2}=$ koefisien regresi $\mathrm{x}_{1}, \mathrm{x}_{2}$

$\mathrm{X}_{1} \quad=$ Variabel bebas (good governance)

$\mathrm{X}_{2} \quad=$ Variabel bebas (budaya organisasi)

e $\quad=$ Kesalahan pengganggu (Standar Error)

Untuk menyelesaikan analisis data ini secara keseluruhan digunakan program SPSS dan semua hasil output data diinterpretasikan satu per satu termasuk didalamnya menentukan koefisien korelasi $(\mathrm{R})$ untuk mengukur tingkat hubungan antara variabel bebas dan variabel terikat serta koefisien determinasi $\left(\mathrm{R}^{2}\right)$ untuk mengukur pengaruh variabel bebas terhadap variabel terikat. 


\section{HASIL DAN PENELITIAN}

Penelitian dilakukan pada pemerintah desa yang ada di Kota Denpasar. Dalam penelitian ini pihak yang dijadikan sampel adalah kepala desa, sekretaris desa, kaur bagian keuangan, Badan Permusyawaratan Desa (BPD), dan Lembaga Pemberdayaan Masyarakat (LPM). Hasil analisis deskriptif disajikan pada tabel 1.

Tabel 1.

Hasil Analisis Deskriptif

\begin{tabular}{lccccc}
\hline & N & Minimum & Maximum & Mean & $\begin{array}{c}\text { Std. } \\
\text { Deviation }\end{array}$ \\
\hline Good Governance & 70 & 37,17 & 60,93 & 49,1307 & 6,82822 \\
Budaya Organisasi & 70 & 14,07 & 31,02 & 23,0810 & 3,70317 \\
Kinerja Aparatur & 70 & 22,81 & 40,46 & 31,1649 & 4,73689 \\
Valid N (listwise) & 70 & & & & \\
\hline Sumber: Data diolah, 2018 & & & & &
\end{tabular}

Dapat ditarik kesimpulan dari Tabel 1 bahwa variabel good governance memiliki nilai minimum sebesar 37,17 dan nilai maksimum sebesar 60,93 dengan nilai rata-rata sebesar 49,1307 serta standar deviasi atau penyimpangan rata-rata sebesar 6,82822. Variabel Budaya Organisasi memiliki nilai minimum sebesar 14,07 dan nilai maksimum sebesar 31,02 dengan nilai rata-rata sebesar 23,0810 serta standar deviasi atau penyimpangan rata-rata sebesar 3,70317. Variabel Kinerja Aparatur memiliki nilai minimum sebesar 22,81 dan nilai maksimum sebesar 40,46 dengan nilai rata-rata sebesar 31,1649 serta standar deviasi atau penyimpangan rata-rata sebesar 4,73689 .

Jika nilai Asymp. Sig. (2-tailed) lebih besar taraf signifikansi yang ditetapkan yaitu 5 persen $(0,05)$, maka data telah berdistribusi normal. Berdasarkan hasil analisis, diperoleh hasil seluruh variabel di atas 0,05 yang artinya data bedistribusi normal. Hasil uji Normalitas dapat dilihat pada Tabel 2. 
Tabel 2.

Hasil Uji Normalitas Data

\begin{tabular}{cccc}
\hline Variabel & Kolmogorov-Smirnov & Sig. & Kesimpulan \\
\hline Good Governance (X1) & 0,851 & 0,463 & Data Normal \\
Budaya Organisasi (X2) & 0,809 & 0,529 & Data Normal \\
Kinerja Aparatur (Y) & 0,813 & 0,524 & Data Normal \\
\hline
\end{tabular}

Sumber: Data diolah, 2018

Untuk mendeteksi ada atau tidaknya multikolinearitas dalam model regresi yaitu mempunyai angka Tolerance $>0,10$ atau mempunyai nilai VIF $<10$. Berdasarkan hasil analisis, dapat dilihat bahwa koefisien Tolerance kedua variabel lebih besar dari 0,10 yaitu serta nilai VIF yang lebih kecil dari 10 . Hasil ini mengindikasikan bahwa tidak terdapat gejala multikolinear dari model regresi yang dibuat. Hasil uji multikolinieritas dapat dilihat pada Tabel 3.

Tabel 3.

Hasil Uji Multikolinieritas

\begin{tabular}{|c|c|c|c|}
\hline Variabel & Tolerance & VIF & Kesimpulan \\
\hline Good Governance (X1) & 0,891 & 1,123 & $\begin{array}{c}\text { Tidak terjadi } \\
\text { multikolinearitas }\end{array}$ \\
\hline Budaya Organisasi (X2) & 0,891 & 1,123 & $\begin{array}{c}\text { Tidak terjadi } \\
\text { multikolinearitas }\end{array}$ \\
\hline
\end{tabular}

Sumber: Data diolah, 2018

Untuk mengetahui ada atau tidaknya heteroskedastisitas yaitu dengan melakukan Uji Glejser dengan meregresi nilai absolut terhadap variabel independen, dengan ketentuan jika nilai signifikan diatas 0,05 maka memiliki arti tidak terjadi heteroskedastisitas. Hasil uji menunjukkan nilai signifikansi lebih dari 0,05 yang artinya model regresi bebas dari gejala heteroskedastisitas. Hasil uji heterokedastisitas dilihat pada Tabel 4.

Tabel 4.

Hasil Uji Heterokedastisitas

\begin{tabular}{ccc}
\hline Variabel & Sig. & Kesimpulan \\
\hline Good Governance (X1) & 0,072 & Tidak terjadi heteroskedastisitas \\
Budaya Organisasi (X2) & 0,523 & Tidak terjadi heteroskedastisitas \\
\hline
\end{tabular}


Ni Putu Rika Raheni dan I.G.A.M Asri Dwija Putri. Pengaruh ...

Hasil Analisis Regresi Linear Berganda dapat dilihat pada tabel 5 dibawah ini.

Tabel 5.

Hasil Uji Analisis Regresi Linear Berganda

\begin{tabular}{|c|c|c|c|c|c|}
\hline \multirow[t]{2}{*}{ Model } & \multicolumn{2}{|c|}{ Unstandardized Coefficients } & \multirow{2}{*}{$\begin{array}{c}\begin{array}{c}\text { Standardized } \\
\text { Coefficients }\end{array} \\
\text { Beta }\end{array}$} & \multirow[t]{2}{*}{$\mathrm{t}$} & \multirow[t]{2}{*}{ Sig. } \\
\hline & $\mathrm{B}$ & Std. Error & & & \\
\hline (Constant) & 4,363 & 3,518 & & 1,240 & 219 \\
\hline Good Governance & ,339 & ,066 & 489 & 5,174 & 000 \\
\hline Budaya Organisasi & 440 & 121 & ,344 & 3,641 & 001 \\
\hline
\end{tabular}

Berdasarkan perhitungan analisis regresi linear berganda, maka didapatkan hasil persamaan regresi sebagai berikut:

$$
\mathrm{Y}=4,363+0,339 \mathrm{X}_{1}+0,440 \mathrm{X}_{2}
$$

Berdasarkan nilai adjusted $\mathrm{R}$ square sebesar 0,452 mengartikan bahwa sebesar 45,2\% variasi kinerja aparatur dipengaruhi olehgood governance dan budaya organisasi, sedangkan sisanya sebesar $54,8 \%$ dipengaruhi oleh faktor lain yang tidak diteliti.

Tabel 6.

Hasil Koefisien Determinasi

\begin{tabular}{ccccc}
\hline Model & $\mathrm{R}$ & $\mathrm{R}$ Square & $\begin{array}{c}\text { Adjusted R } \\
\text { Square }\end{array}$ & $\begin{array}{c}\text { Std. Error of the } \\
\text { Estimate }\end{array}$ \\
\hline 1 &, $684^{\mathrm{a}}$ &, 468 &, 452 & 3,50648
\end{tabular}

a. Predictors: (Constant), Budaya Organisasi, Good Governance

Sumber: Data diolah, 2018

Berdasarkan perhitungan, diperoleh nilai $F_{h i t u n g}$ sebesar 29,460. Sedangkan nilai $\mathrm{F}_{\text {tabel }}$ dihitung dengan menggunakan rumus $=\mathrm{F}_{\{\alpha,(\mathrm{k}-1),(\mathrm{n}-\mathrm{k})\}}$ sehingga $\mathrm{f}_{\text {tabel }}=$ $\mathrm{f}_{\{0,05,(2),(67)\}}$, berdasarkan tabel distribusi $\mathrm{F}$ maka besarnya $\mathrm{f}_{\text {tabel }}$ adalah 3 ,13.Hasil dari uji $\mathrm{F}$ diperoleh $\mathrm{f}_{\text {hitung }}>\mathrm{f}_{\text {tabel }}=29,460>3,13$, sehinggga $\mathrm{H}_{0}$ ditolak dan $\mathrm{Ha}$ diterima. Hasil ini berarti variabel bebas yaitu good governance (X1) dan budaya 
organisasi (X2) berpengaruh signifikan secara serempak atau bersama-sama terhadap variabel terikat yaitu kinerja aparatur (Y).

Tabel 7.

Hasil Uji F

\begin{tabular}{llrrrrc}
\hline Model & & Sum of Squares & Df & Mean Square & F & Sig. \\
\hline 1 & Regression & 724,441 & 2 & 362,221 & 29,460 &, $000^{\mathrm{b}}$ \\
& Residual & 823,791 & 67 & 12,295 & & \\
& Total & 1548,232 & 69 & & & \\
\hline
\end{tabular}

Sumber: Data diolah, 2018

Berdasarkan hasil perhitungan, diperoleh nilai Sig. sebesar 0,000 dan nilai $t_{\text {hitung }}$ sebesar 5,174. Sedangkan nilai $t_{\text {tabel }}$ dihitung menggunakan tabel $t$ dengan $\alpha$ (level of significant $)=0,05$ dan $\mathrm{df}($ degree of freedom $)=\mathrm{n}-3=70-3=67$ sehingga didapatkan nilai $\mathrm{t}_{\text {tabel }}$ sebesar 1,996 . Hasil dari uji $\mathrm{t}$ ini yaitu $\mathrm{t}_{\text {hitung }}$ lebih besar dari $\mathrm{t}_{\text {tabel }}(5,174>1,996)$, artinya $\mathrm{H}_{0}$ ditolak dan Ha diterima. Sehingga keputusannya adalah terdapat pengaruh positif dan signifikan secara parsial antara good governance dengan kinerja aparatur.

Tabel 8.

Hasil Uji t

\begin{tabular}{|c|c|c|c|c|c|c|}
\hline & \multirow[t]{2}{*}{ Model } & \multicolumn{2}{|c|}{ Unstandardized Coefficients } & \multirow{2}{*}{$\begin{array}{c}\text { Standardized } \\
\text { Coefficients }\end{array}$} & \multirow[t]{2}{*}{$\mathrm{t}$} & \multirow[t]{2}{*}{ Sig. } \\
\hline & & B & Std. Error & & & \\
\hline \multirow[t]{3}{*}{1} & (Constant) & 4,363 & 3,518 & & 1,240 & ,219 \\
\hline & $\begin{array}{l}\text { Good } \\
\text { Governance }\end{array}$ & 339 & 066 & ,489 & 5,174 & 000 \\
\hline & $\begin{array}{l}\text { Budaya } \\
\text { Organisasi }\end{array}$ & , 440 &, 121 & ,344 & 3,641 & ,001 \\
\hline
\end{tabular}

Sumber: Data diolah, 2018

Berdasarkan hasil perhitungan, diperoleh nilai Sig. sebesar 0,001 dan nilai $t_{\text {hitung }}$ sebesar 3,641. Sedangkan nilai $t_{\text {tabel }}$ dihitung menggunakan tabel $t$ dengan $\alpha$ (level of significant $)=0,05$ dan $\mathrm{df}($ degree of freedom $)=\mathrm{n}-3=70-3=67$ sehingga didapatkan nilai $t_{\text {tabel }}$ sebesar 1,996 . Hasil dari uji $t$ ini yaitu $t_{\text {hitung }}$ lebih besar dari $\mathrm{t}_{\text {tabel }}(3,641>1,996)$, artinya $\mathrm{H}_{0}$ ditolak dan Ha diterima. Sehingga keputusannya 
Ni Putu Rika Raheni dan I.G.A.M Asri Dwija Putri. Pengaruh ...

adalah terdapat pengaruh positif dan signifikan secara parsial antara budaya organisasi dengan kinerja aparatur.

Berdasarkan hasil penelitian menunjukkan bahwa good governance berpengaruh positif pada kinerja aparatur sehingga hipotesis pertama dalam penelitian ini diterima. Halim \& Damayanti, (2007) menyatakan bahwa dengan adanya otonomi daerah pendayagunaan aparatur merupakan suatu tuntutan yang mampu mendukung kelancaraan dan keterpaduan pelaksanaan tugas dan fungsi penyelenggaraan pemerintah negara dan pembangunan dengan mempraktikkan prinsip-prinsip good governance. Tata kelola yang baik atau Good Governance adalah suatu tatanan kehidupan berbangsa dan bernegara yang pola sikap dan pola tindak pelakunya dilandasi prinsip-prinsip dan karakteristik tertentu (Mardiasmo, 2004). Frederickson, (2002) memberikan pengertian mengenai good governance dimana suatu keahlian atau spesialisasi, layanan pada warga sipil, pembangunan lembaga, ilmu administrasi, dan asumsi dari kepentingan umum secara kolektif.

Penelitiannya oleh Agus et al., (2018) mengenai pengaruh good governance pada kinerja pemerintahan di kota Bandung menyatakan bahwa terdapat pengaruh yang signifikan antara penerapan prinsip good governance pada kinerja pemerintah daerah kota Bandung dimana terdapat korelasi yang sangat kuat antara penerapan prinsip good governance pada kinerja pemerintah daerah, apabila terjadi satu kenaikan atau penurunan tingkat good governance maka akan mempengaruhi pula kinerja pemerintahan.

Penelitian oleh Kita, (2017) mengenai pengaruh good governance terhadap kinerja aparatur di Kabupaten Klungkung mendapatkan hasil bahwa good 
governance berpengaruh positif terhadap kinerja aparatur. Berdasarkan pernyataan sebelumnya dan ditambah dengan hasil penelitian ini mengungkapkan bahwa apabila semakin baik penerapan good governance maka semakin baik pula kinerja pemerintahan tersebut.

Berdasarkan hasil penelitian menunjukkan bahwa budaya organisasi berpengaruh positif pada kinerja aparatur sehingga hipotesis kedua dalam penelitian ini diterima. Budaya adalah salah satu dasar dari asumsi untuk mempelajari dan memecahkan suatu masalah yang ada didalam suatu organisasi. Suatu organisasi termasuk birokrasi pemerintahan didirikan sebagai suatu wadah untuk mencapai suatu atau beberapa tujuan. Organisasi tersebut harus mengelola berbagai dan rangkaian kegiatan yang diarahkan menuju tercapainya tujuan organisasi. Pelaksanakan rangkaian kegiatan dalam organisasi dilakukan oleh manusia (humanbeing) yang bertindak sebagai aktor atau peserta dalam organisasi yang bersangkutan, maka dengan sendirinya kinerja (performance) organisasi yang bersangkutan banyak tergantung pada perilaku manusia yang terdapat dalam organisasi tersebut.

Budaya organisasi merupakan nilai-nilai yang menjadi pedoman sumber daya manusia untuk menghadapi permasalahan eksternal dan usaha penyesuaian integrasi ke dalam organisasi sehingga masing-masing anggota organisasi harus memahami nilai-nilai yang ada dan bagaimana mereka bertingkah laku atau berprilaku. Jadi dengan demikian pengaruh positif antara budaya organisasi terhadap kinerja penyelenggara pemerintahan desa dapat diwujudkan melalui budaya organisasi yang senantiasa memberikan pelayanan yang baik dan sepenuh 
Ni Putu Rika Raheni dan I.G.A.M Asri Dwija Putri. Pengaruh ...

hati kepada masyarakat, semakin baik budaya organisasi yaitu mampu mempertahankan identitas dari organisasi itu sendiri serta mampu berfungsi sebagai wadah dalam penyelesaian masalah serta mampu megayomi masyarakatnya menjadi sejahtera, maka kinerja pemerintah desa akan semakin baik.

Hasil penelitian ini didukung oleh penelitian Widasari \& Putri, (2018) yang menyatakan bahwa budaya organisasi berpengaruh positip pada kinerja manajerial pemerintahan desa, sejalan dengan penelitian Kita, (2017) yang berpendapat bahwa budaya organisasi berpengaruh pada kinerja aparatur.

Hasil penelitian ini dapat membuktikan teori yang digunakan dalam penelitian ini yaitu teori keagenan. Selain itu, penelitian ini juga menambah referensi, informasi, wawasan, dan memberikan pemahaman yang lebih luas berkaitan dengan pengaruh good governance dan budaya organisasi pada kinerja aparatur penyelenggara pemerintahan desa.

Hasil penelitian ini dapat menjadi pertimbangan aparatur penyelenggara pemerintahan desa bahwa pentingnya penerapan good governance dan budaya organisasi pada kinerja. Berdasarkan hasil pembahasan, maka kinerja aparatur akan meningkat dengan menerapkan good governance dan budaya organisasi.

\section{SIMPULAN}

Good governance berpengaruh positif pada kinerja aparatur penyelenggara pemerintahan desa di Kota Denpasar. Semakin meningkatnya penerapan good governance maka semakin meningkat pula kinerja aparatur. Budaya organisasi 
berpengaruh positif pada kinerja aparatur penyelenggara pemerintahan desa di Kota Denpasar. Semakin baik budaya organisasi maka akan semakin baik kinerja aparatur.

Aparatur penyelenggara pemerintahan desa khususnya di Kota Denpasar diharapkan dapat menerapakan good governance dan budaya organisasi dengan lebih baik lagi agar dapat meningkatkan kinerja yang lebih baik pula. Penelitian selanjutnya disarankan untuk menggunakan sampel yang lebih luas, misal seluruh desa yang ada di Kota Denpasar, maupun seluruh desa di Bali.

Besarnya nilai Adjusted $R$ Square dalam penelitian ini sebesar 0,452 mengartikan bahwa sebesar 45,2\%variasi kinerja aparatur dipengaruhi olehgood governance dan budaya organisasi, sedangkan sisanya sebesar 54,8\% dipengaruhi oleh faktor lain yang tidak diteliti. Penelitian selanjutnya disarankan untuk menambah variabel bebas lainnya yang diduga dapat berpengaruh pada kinerja aparatur penyelenggara pemerintahan desa seperti gaya kepemimpinan, partisipasi anggaran, komitmen organisasi, kompetensi.

\section{REFERENSI}

Acintya, I. G. A. A. D., \& Putri, I. G. A. M. A. D. P. (2015). Kinerja Pemerintah Kota Denpasar dalam Implementasi SAKIP dan Penerapan G Governance. E-Jurnal Akuntansi Universitas Udayana, 12(2).

Agus, I. G., Putra, S., Pande, I. M., \& Putra, D. (2018). Pengaruh Good Governance dan Sistem Pengendalian Intern Pemerintah Pada Kinerja Pemerintah Daerah. E-Jurnal Akuntansi Universitas Udayana, 25(3), 17201743.

Asian Development Bank. (1995). Governance: Sound Development Management. Retrieved from http://www.adb.org/sites/default/files/institutional- 
document/32027/govpolicy.pdf

Asmara, I. K. J., \& Widanaputra, A. A. G. P. (2017). Pengaruh Gaya Kepemimpinan Transformasional dan Budaya Organisasi pada Kinerja Organisasi dengan Motivasi Kerja sebagai Pemoderasi. E-Jurnal Akuntansi Universitas Udayana, 18(2), 1575-1603.

Development, O. for E. C.-O. and. (2002). Annual Report.

Dzulkifli, M. (2013). Pengaruh Gaya Kepemimpinan, Motivasi, Disiplin Kerja, Kompetensi dan Budaya Organisasi terhadap Kinerja Pegawai (Studi Empiris pada Direktorat Budidaya dan Pascapanen Florikultura). Skripsi. Sarjana Jurusan Manajemen Fakultas Ekonomi dan Bisnis Universitas Islam Negeri Syarif Hidayatullah.

Eisenhardt, K. M. (1989). Agency Theory: An Assessment and Review. Academy of Management, 14(1), 57-74.

Frederickson, H. G. (2002). The Spirit of Public Administration. PS - Political Science and Politics, 35(4), 689-694. https://doi.org/10.1017/S104909650200118X

Halim, A., \& Damayanti, T. (2007). Pengelolaan Keuangan Daerah (Edisi: Ked). Yogyakarta: UPP STIM YKPN.

Hasanah, C. U., \& Suartana, I. W. (2014). Pengaruh Interaksi Motivasi dan Budaya Organisasi pada Hubungan anara Partisipasi Penyusunan Anggaran dengan Senjangan Anggaran. E-Jurnal Akuntansi Universitas Udayana, 6(1), $46-62$.

Hofstede, G. (1984). Cultural Dimensions In Management And Planning. Asia Pacific Journal of Management, (January), 81-99.

Holmes, S., \& Marsden, S. (1996). An exploration of the espoused organizational cultures of public accounting firms. Accounting Horizons, 10(3), 26-53.

Jatilaksono, R. S., \& Indartono, S. (2016). The Impact of Work Discipline and Organizational Culture Toward Employee Performance. Jurnal Manajemen Bisnis Indonesia, 5(6), 588-603.

Jensen, M. C., \& Meckling, W. H. (1976). Theory of Firm: Manajerial Behaviour, Agency Cost, and Ownership Structure. Journal of Financial Economics, (4), 305-360.

Keban, J. T. (1995). Indikator Kinerja Pemerintah Daerah: Pendekatan Manajemen dan Kebijakan,. Makalah, Seminar Sehari, Fisipol UGM, 
Yogyakarta.

Kita, N. L. M. N. S. (2017). Pengaruh Partisipasi Anggaran, Komitmen Organisasi, Budaya Organisasi, dan Kompetensi terhadap Kinerja Aparatur Penyelenggara Pemerintah Desa di Kabupaten Klungkung. Tesis. Magister Akuntansi Program Pascasarjana Universitas Udayana.

Lestari, M. I. (2013). Pengaruh Budaya Organisasi dan Pengendalian Intern Terhadap Penerapan Prinsip-Prinsip Good Corporate Governance (Studi Empiris Pada Rumah Sakit Umum di Kota Padang). Jurnal Akuntansi Universitas Negeri Padang, 1(3).

Mahoney, T. A., Jerdee, T. H., \& Carrol, S. J. (1963). Development of Managerial Performance: A Research Approach. Southwestern Publishing C., Cincinati, Ohio.

Mardiasmo. (2004). Akuntansi Sektor Publik (Edisi Kedu). Yogyakarta: Penerbit Andi.

Milani, K. (1975). The Relationship of Participation in Budget-Setting to Industrial Supervisor Performance and Attitudes: A Field Study Linked references are available on JSTOR for this article: The Relationship of Participation in Budget-Setting to Industrial Supervisor. The Accounting Review, 50(2), 274-284. Retrieved from https://www.jstor.org/stable/244709

Muhammad, K. (2017). Mewujudkan Good Governance di Pemerintah Kota Malang Melalui Implementasi Undang-undang No. 14 tahun 2008 tentang Keterbukaan Informasi Publik. Publisia: Jurnal Ilmu Administrasi Publik, 2(2), 146-157. https://doi.org/10.26905/pjiap.v2i2.2021

Mulyawan, B. (2009). Pengaruh Pelaksanaan Good Governance Dan Pengendalian Intern Terhadap Kinerja Organisasi. Skripsi. Sarjana Fakultas Ilmu Sosial dan Ilmu Politik Universitas Sumatera Utara.

Pradipto, A. (2008). Pengaruh Penerapan Prinsip Good Corporate Governance terhadap Kinerja Keuangan Perusahaan. Skripsi. Sarjana Jurusan Akuntansi Fakultas Ekonomi Universitas Widyatama.

Robbins, S. P. (2006). Prinsip-Prinsip Perilaku Organisasi,Terjemahan (Edisi Keli). Jakarta: Penerbit Airlangga.

Sabrinna, A. I. (2010). Pengaruh Corporate Governance dan Struktur Kepemilikan Terhadap Kinerja Perusahaan. Skripsi. Semarang: Universitas Diponegoro. Universitas Diponegoro.

Soraya, B. E., \& Suardana, K. A. (2018). Budaya Organisasi Sebagai Pemoderasi 
Pengaruh Good Corporate Governance pada Kinerja Keuangan Bank Pembangunan Daerah Bali Fakultas Ekonomi dan Bisnis Universitas Udayana ( Unud ), Bali , Indonesia Fakultas Ekonomi dan Bisnis Universitas Udayana ( Unud ), 23(3), 2414-2443.

Wardani, R. K., Mukzam, M. D., \& Mayowan, Y. (2016). Pengaruh Organisasi Terhadap Kinerja Karyawan (Studi Pada Karyawan PT Karya Indah Buana Surabaya). Jurnal Administrasi Bisnis, 31(1), 58-65.

Widasari, K. I., \& Putri, I. G. A. M. A. D. P. (2018). Pengaruh Good Governance dan Budaya Organisasi Terhadap Kinerja Manajerial Penyelenggara Pemerintahan Desa di Kabupaten Badung. E-Jurnal Akuntansi Universitas Udayana, 22(2), 1308-1334.

Widjaja, H. A. . (2005). Penyelenggaraan Otonomi di Indonesia Dalam Rangka Sosialisasi UU No. 32 Tahun 2004 Tentang Pemerintahan Daerah. Jakarta: PT Rajagrafindo Persada.

Yamin, M. (2014). Pola Budaya dan Kinerja Organisasi Publik (Studi Pada Pemerintah Kota Kendari). Jurnal Birokrat Ilmu Administrasi Publik.

Yang, M. R. P., \& Suartana, I. W. (2017). Pengaruh Good Governance, Pengelolaan Keuangan Daerah dan Sistem Pengendalian Intern Pemerintah pada Kinerja Pemerintah Daerah. E-Jurnal Akuntansi Universitas Udayana, 21(2), 1346-1372. 